\title{
Dietary Sugar Beet Tops and Prebiotic Effect on Nutrient Digestibility, Caecal Activity and Organ Histology of Weaning Rabbits
}

\author{
Hayam M. A. Abo El-Maaty ${ }^{1}$, Sara Kh. Sherif ${ }^{1} \&$ Lina S. A. Foda ${ }^{1}$ \\ ${ }^{1}$ Poultry Production Department, Faculty of Agriculture, Mansoura University, Mansoura, Egypt \\ Correspondence: Hayam M. A. Abo El-Maaty, Poultry Production Department, Faculty of Agriculture, Mansoura \\ University, Mansoura, Egypt. Tel: 20-100-896-1731. E-mail: hayam151@yahoo.com
}

Received: December 7, 2017

Accepted: January 22, 2018 Online Published: February 15, 2018

doi:10.5539/jas.v10n3p162

URL: https://doi.org/10.5539/jas.v10n3p162

\begin{abstract}
The current study was designed to evaluate the effect feeding weaning rabbits sugar beet tops (SBT) with prebiotic on digestibility of nutrients and caecal microbial activity, volatile fatty acids estimation and organs histology. Fifty four 6-week-old unsexed weaning NZW rabbits were randomly distributed in a factorial $(3 \times 2)$ design to six equal groups. Sugar beet tops (SBT) was used at levels $0.0,20$ or $30 \%$ of the diet instead of the percent of alfalfa hay in the control diet in presence of $1.0 \mathrm{~g} / \mathrm{kg}$ diet or absence of prebiotic (Perfect). Digestibility coefficients of dry matter (DM), crude protein (CP), ether extract (EE) and NFE of 12-week old NZW rabbits were improved by feeding SBT-containing diets. Dietary SBT level had no significant effect on $\mathrm{pH}$ value, TVFA, $\mathrm{s}$ and $\mathrm{NH}_{3}-\mathrm{N}$ values for caecum content of 12 weeks old NZW rabbits, however, total bacteria, $E$. coli and lactobacillus counts were significantly affected. Feeding SBT-containing diets did not alter plasma concentrations of AST and ALT of 12-week-old rabbits. Dietary prebiotic had a positive effect on the digestibility coefficients of DM, OM, CP, EE, CF and NFE of growing rabbits. Added prebiotic had a positive effect on caecal fermentative activities and caecal microbial activity of growing rabbits. The $\mathrm{pH}$ value, ammonia-N level, total bacteria and lactobacillus counts of rabbits fed prebiotic-supplemented diets were significantly higher but $E$. coli count was reduced as compared to control ones. This study concluded that sugar beet tops can be safely used in rabbit diets up to $30 \%$ instead of alfalfa hay.
\end{abstract}

Keywords: caecal activity, digestibility, organs histology, rabbits, sugar beet tops

\section{Introduction}

It is recognized that the use of antibiotics as growth promoters in the European Union and in Egypt is a serious hazard to humans, animals and the surrounding environment, so many research has focused on the development of alternative strategies to maintain health and performance status in modem livestock production systems. There are now many substances that are used as natural growth promoters as antibiotic alternatives such as prebiotics. This product has the potential to beneficially affect intestinal health and growth performance by establishing and maintaining a well-balanced gut microflora which protects the host against pathogenic bacteria. Prebiotics are oligosaccharides that are not digestible by animal, but can be fermented in the intestine and act as a nutrient source for lactic acid-producing bacteria such as specific strains of bifidobacteria (Wenk, 2003). Rabbits are suitable for meat production in the subtropics because of its high fecundity, short generation time and good feed conversion. (McNitt et al., 2013). Nutrition is one of the key factors determining the success of rabbit economic production (Daader \& Seleem, 1999). Agricultural waste is inexpensive, untraditional feedstuffs in animal diets and may contribute to solving the problem of feed, reducing the price of the rabbits ration and solving the problem of environmental pollution of this agro-industrial (El-Kerdawy, 1997). In Egypt, about 1.5 million tons of sugar beet tops are produced yearly. Using sugar beet tops such an agricultural by-product as a feed ingredient for fattening rabbits can participate in solving the problem of feedstuffs' shortage and reduce the environmental pollution (Abo El-Maaty et al., 2017). Prebiotics should create unfavorable conditions for pathogenic microorganisms in the caecum of rabbits. The results of Morisse et al. (1993) showed that the effect of fructo-oligosaccharides (FOS) in rabbit caecum: E. coli population decreased, the volatile fatty acids production increased while, the ammonia levels in caecal contents decreased. But Maertens et al. (2006), testing FOS and inulin, only got an effect on the molar proportions of fatty acids. As far as other prebiotics are concerned, both galacto-oligosaccharides (GOS) (Peeters et al., 1992) and mannan-oligosaccharides (MOS) (Mourão et al., 2006) 
were able to increase the caecal volatile fatty acids levels. On the contrary Gidenne (1995) did not found any effect of galacto-oligosaccharides (GOS) on caecal volatile fatty acids pattern. Fractions with a lower degree of polymerization may be hydrolyzed by microbes residing in the upper intestine, especially when the rabbit is actively practicing caecotrophy (Carabaño et al., 2001). Maertens et al. (2006) showed that, when rabbits are not allowed to practice caecotrophy, the ileal digestibilities of FOS and inulin are similar and not far from $50 \%$. As to the effect on gut morphology, Mourão et al. (2006) reported that the length of ileal villi was increased by MOS addition; this may be of the reduction in microbial counts, which they also found. Differences in the results obtained with prebiotics can be explained by differences in the experimental designed, e.g. number of experimental animals, hygienic conditions, nature and amount of prebiotic added to the diet. This latter factor has been stressed by several researchers (Mourão et al., 2006). If the amounts that must be added are very high, the use of prebiotics is compromised by cost. Also, it is just possible that prebiotics which show benefits in long-living animals, humans in particular, do not show them in short-living species, such as the rabbit. Therefore, the present study was designed to evaluate the response of NZW rabbits to dietary sugar beet tops with prebiotic (Prefect) on nutrient digestibility, caecal microbial activity, volatile fatty acids estimation and organs histology.

\section{Materials and Methods}

The present research was carried out at the Experimental Unit of Rabbits Research, Faculty of Agriculture, Mansoura University, during the period from March to April, 2015. The proximate analyses of the tested materials and the experimental diets were undertaken at the Laboratory of Poultry Production Department, Faculty of Agriculture, Mansoura University, Egypt.

The present research conducted to elucidate the possibility of feeding the sugar beet tops-containing rations $(0.0$, 20 and 30\%) in presence or absence of prebiotic (Perfect) on digestibility of nutrients, caecal microbial activity and volatile fatty acids estimation, certain blood plasma constituents and histological characterization of liver, ileum and cecum of rabbits.

\subsection{Experimental Animals and Diets}

Fifty four 42-days-old unsexed NZW growing rabbits, with nearly similar initial live body weights $(650 \pm 35 \mathrm{~g})$, were randomly distributed, in a factorial arrangement of treatments, to six equal experimental treatments, three replications/treatment. Six experimental pelleted rations were formulated to meet the nutrient requirements of post-weaning rabbits, according to the National Research Council (NRC, 1977). Alfalfa hay content in the basal diet $(40 \%)$ was replaced by $0.0,20$ or $30 \%$ of SBT (equivalent to replacement ratios of $0.0,50$ or $75 \%$ of AH) in presence $(1.0 \mathrm{~g} / \mathrm{kg})$ or absence of prebiotic (Perfect) fortification. As declared by the manufacturer, the prebiotic added (Perfect) is a buffered blend of specific carboxylic acids on a unique mineral carrier system combined with a fructo-oligosaccharide source. The feedstuffs composition and nutrient substances of the experimental rations are illustrated in Table 1.

\subsection{Housing and Management}

Each replicate group of rabbits ( 3 animals) was kept in a galvanized wire-net $(50 \times 50 \times 45 \mathrm{~cm})$ and provided with a feeder and a nipple drinker, and fed its respective experimental diet from 6 to 12 weeks of age. All experimental rabbits were kept in a naturally ventilated building and subjected to similar environmental, managerial and hygienic conditions. Pelleted feed and fresh water were provided on an ad libitum basis.

\subsection{Criteria of Response}

\subsubsection{Digestibility Trials}

During the $12^{\text {th }}$ week of age, 6 digestibility trials were done using the same replicates groups of the experimental rabbits using total collection method. Animals were fed their respective experimental diets for 4 days, in which daily feed intake and feces voided were quantitatively determined. Feces produced daily for each replicate group was collected quantitatively in polyethylene bags and stored at $-20{ }^{\circ} \mathrm{C}$ for later analysis (Perez et al., 1995). Fecal samples were dried in a forced air oven at $70{ }^{\circ} \mathrm{C}$ for $72 \mathrm{hr}$ (Air-dried samples) then ground and placed in screw-top glass jars until chemical analyses. Dry matter (DM), crude protein (CP), ether extract (EE), crude fiber (CF) and ash content of the feces as well as those of feed were determined according to AOAC (2000) and expressed on a dry matter basis. Nitrogen free extract estimated as follows: (NFE) $=100-(\mathrm{CP}+\mathrm{EE}+\mathrm{CF}+$ Ash). The apparent digestion coefficients for DM, OM, CP, EE, CF and NFE were calculated.

\subsubsection{Caecal Microbial Activity and Volatile Fatty Acids Estimation}

At 12 weeks of age from three animals per treatment, after sacrificing, individual caecum fluid samples were collected to estimate caecal microbial activity and volatile fatty acids (VFA's) content. About $20 \mathrm{ml}$ of caecum 
fluid was collected at 18 hours post-feeding. The caecum fluid samples were filtered through two layers of surgical gauze before the determination of caecal characteristics. The $\mathrm{pH}$ value of caecum fluid was estimated immediately using a battery-operated $\mathrm{pH}$ meter. The VFA's and ammonia-N $\left(\mathrm{NH}_{3}-\mathrm{N}\right)$ concentrations were determined in wet samples of caecal content according to the method of Vernay and Marty (1984).

\subsubsection{Caecal Micro Flora}

Rabbits selected for caecal measurements were immediately sacrificed and opened up and samples of the caecal contents were immediately collected. The caecal contents were put on ice until they were transported to the laboratory for enumeration of microbial population. Coliform bacteria were assessed on selective agar incubated aerobically, while Lactobacilli were anaerobically assessed on selective agar. Microbial counts were measured according to the methods of Xia et al. (2004).

\subsubsection{Blood Parameters of Rabbits}

At 12 weeks of age, three blood samples per experimental group of rabbits were taken during slaughtering in heparinized test tubes. Rabbit's management and handling during the study were carried out to the highest standards of ethics in accordance with the guidelines of the local animal research ethics commit at Mansoura University associated with the ethics of animal use in practical experiments. Blood samples were immediately centrifuged at $3000 \mathrm{rpm}$ for 15 minutes in order to separate blood plasma. Plasma samples were frozen at $-20{ }^{\circ} \mathrm{C}$ until later analysis. Creatinine, Urea concentration, AST, ALT, SOD activity and MDA concentration were estimated using commercial Kits.

\subsubsection{Histological Examination of Organs}

Representative tissue samples from liver, ileum and caecum were carefully dissected and immediately fixed in adequate volume of $10 \%$ formalin solution. The paraffin method technique was used to prepare permanent sections as described by Junqueira et al. (1981). Briefly, samples were dehydrated in ascending concentrations of ethyl alcohol solutions ranged from $70 \%$ to absolute ethanol alcohol. Samples were cleared in xylene, and the embedded in melted paraffin wax to obtain tissues blocks. They were sectioned (4-5 microns thick) and mounted on glass slides, then stained with the ordinary Hematoxyline and eosin staining procedure. The histological sections were conducted at the Pathology Laboratory, Faculty of veterinary Medicine, Cairo University, Egypt. Sections were examined under light microscope and photographed by using a digital camera. 
Table 1. Composition of the tested diets for weaning rabbits from 6 to 12 weeks of age

\begin{tabular}{|c|c|c|c|}
\hline \multirow{2}{*}{ Ingredients $\%$} & \multicolumn{3}{|c|}{ Experimental diets } \\
\hline & Control & $20 \%$ SBT & $30 \%$ SBT \\
\hline Soybean meal, 44\% CP & 12.00 & 14.00 & 14.50 \\
\hline Yellow corn & 14.00 & 8.00 & 7.00 \\
\hline Wheat bran & 3.00 & 7.00 & 10.50 \\
\hline Barley grain & 26.20 & 26.20 & 23.20 \\
\hline Alfalfa hay & 40.00 & 20.00 & 10.00 \\
\hline Sugar beet tops (SBT) & - & 20.00 & 30.00 \\
\hline Molasses & 2.00 & 2.00 & 2.00 \\
\hline Dicalcium phosphate & 1.20 & 1.20 & 1.20 \\
\hline Limestone & 1.00 & 1.00 & 1.00 \\
\hline Vit. + Min. Mix. ${ }^{(1)}$ & 0.40 & 0.40 & 0.40 \\
\hline Sodium chloride & 0.20 & 0.20 & 0.20 \\
\hline Total & 100 & 100 & 100 \\
\hline \multicolumn{4}{|l|}{ Calculated analysis } \\
\hline Digestible energy, $\mathrm{kcal} / \mathrm{kg}$ & 2525 & 2542 & 2547 \\
\hline Crude protein, $\%$ & 16.03 & 16.14 & 16.07 \\
\hline Crude fiber, $\%$ & 13.67 & 12.43 & 11.85 \\
\hline Ether extract, \% & 2.25 & 1.82 & 1.69 \\
\hline Lysine, $\%$ & 0.76 & 0.69 & 0.65 \\
\hline Meth., \% & 0.21 & 0.19 & 0.18 \\
\hline Meth. + Cyst., \% & 0.52 & 0.44 & 0.40 \\
\hline Calcium, $\%$ & 1.28 & 1.07 & 0.97 \\
\hline Total phosphorus, $\%$ & 0.57 & 0.57 & 0.58 \\
\hline \multicolumn{4}{|c|}{ Determined analysis, DM basis } \\
\hline Dry matter, $\%$ & 92.00 & 91.11 & 91.05 \\
\hline Organic matter, $\%$ & 83.10 & 82.09 & 81.62 \\
\hline Crude protein, $\%$ & 17.42 & 17.71 & 17.65 \\
\hline Crude fiber, $\%$ & 14.86 & 13.64 & 13.02 \\
\hline $\mathrm{NDF}^{(2)}, \%$ & 80.41 & 76.34 & 77.14 \\
\hline $\mathrm{ADF}^{(2)}, \%$ & 18.19 & 14.64 & 15.72 \\
\hline $\mathrm{ADL}^{(2)}, \%$ & 3.62 & 2.36 & 2.74 \\
\hline Ether extract, \% & 2.75 & 2.00 & 1.86 \\
\hline Ash, $\%$ & 8.90 & 9.02 & 9.43 \\
\hline Nitrogen free extract, $\%$ & 56.07 & 57.63 & 58.04 \\
\hline
\end{tabular}

Note. ${ }^{(1)}$ Each $3 \mathrm{Kg}$ vitamin and mineral mixture contained $12000000 \mathrm{IU}$ Vit. $\mathrm{A}, 2500000 \mathrm{IU}$ Vit. $\mathrm{D}_{3}, 10000 \mathrm{mg}$ Vit. E, $2500 \mathrm{mg}$ Vit. $\mathrm{K}_{3}, 1000 \mathrm{mg}$ Vit. $\mathrm{B}_{1}, 4000 \mathrm{mg}$ Vit. $\mathrm{B}_{2}, 1500 \mathrm{mg}$ Vit. $\mathrm{B}_{6}, 10 \mathrm{mg}$ Vit. $\mathrm{B}_{12}, 10000 \mathrm{mg}$ Pantothenic acid, $20000 \mathrm{mg}$ Nicotinic acid, $1000 \mathrm{mg}$ Folic acid, $50 \mathrm{mg}$ Biotin, $500 \mathrm{mg}$ Choline chloride, $60 \mathrm{mg}$ Manganese, $55 \mathrm{mg}$ Zinc, $100 \mathrm{mg}$ Selenium,1000 mg Iodine, $35 \mathrm{mg}$ Iron, $10 \mathrm{mg}$ Copper, $250 \mathrm{mg}$ Cobalt and Carrier $\mathrm{CaCo}_{3}$ to $3 \mathrm{~kg}$.

${ }^{(2)} \mathrm{NDF}=$ Nutrient detergent fiber, $\mathrm{ADF}=$ Acid detergent fiber, $\mathrm{ADL}=$ Acid detergent lignin.

\subsection{Statistical Analysis}

Data were statistically analyzed using Two-way analysis of variance of SAS Program (SAS, 2004). Significant differences among means $(\mathrm{P} \leq 0.05)$ were separated using Duncan's new multiple ranges test (Duncan, 1955).

\section{Results and Discussion}

\subsection{Digestibility Traits of Rabbits}

\subsubsection{Effect of Dietary SBT Level}

The effects of replacing dietary alfalfa hay by dried SBT with or without a prebiotic addition on nutrient digestibility of growing rabbits are presented in Table 2. These results showed that digestibility coefficients of dry matter (DM), organic matter (OM), crude protein (CP), ether extract (EE) and nitrogen free extract (NFE) of 12 weeks old NZW rabbits were positively affected $(\mathrm{P} \leq 0.05)$ by feeding the SBT-containing diets $(20 \%$ and $30 \%$ ) compared with their control group. The improved nutrient digestibility, reported herein, harmonizes with the findings of Gaafar et al. (2014), who found that replacing dietary clover hay by strawberry vine produced beneficial effects on digestibility coefficients of DM, OM, CP, EE, CF and NFE of rabbits as compared to their 
control counterparts. The current results agree also with the findings of Gaafar et al. (2010), who reported that feeding growing rabbits on diets containing dried SBT silage in place of dietary clover hay significantly improved the digestibility coefficients of DM, OM, CP, CF, EE and NFE. Similarly, results of the present study are in agreement with those obtained by Taie et al. (1996) and Tag El-Din et al. (2000), who found that feeding growing rabbits on diets containing SBT resulted in significantly higher digestibility coefficients of DM, OM, CP, EE and NFE. In this respect, Sarhan (2005) found that the digestible crude protein of diet contained $30 \%$ pea pods hulls was significantly higher than that of the control diet.

On the other hand, Gidenne (2003) observed a decrease in nutrient digestibility of rabbits fed lemon and orange pulps; he suggested that this might be related to the high fiber contents (especially pectin) of these agro-industrial by-products. In addition, Hussien (2009) observed that apparent EE digestibility of growing rabbits was not affected by either pea vines, green bean vines or squash vines when their dietary inclusion level reached $35 \%$.

\subsubsection{Effect of Prebiotic Supplementation}

Apart from dietary SBT level, added dietary prebiotic had a positive effect $(\mathrm{P} \leq 0.05)$ on the digestibility coefficients of DM, OM, CP, EE, CF and NFE of growing rabbits (Table 2). The beneficial effect exerted by dietary prebiotic on nutrient digestibility by the experimental rabbits may be due to its stimulating action on caecal microbial activity, and thus improving the digestion efficiency. The high levels of organic acids that produced due to increased microbial fermentation are involved in balancing the microbial population in the small intestine and/or can stimulate the activities of the digestive enzymes (Knarreborge et al., 2002). Our data are in accordance with those reported by Pinheiro et al. (2004), who observed higher feed digestibility in MOS-supplemented rabbits compared with their control group, and suggested that the positive effect of MOS on nutrient digestibility might be due to improving the intestinal morphology, as MOS may increase villi height: crypt depth at the ileum, which induce an increased feed digestion and absorbability via increasing the intestinal absorption surface area. In this regard, El-Gohary and Abo El-Maaty (2014) reported that dietary supplementation of prebiotic (MOS) had a positive effect on nutrient digestibility and nutritive values for growing NZW rabbits.

\subsubsection{Effect of Interaction between Dietary SBT and Prebiotic Supplementation}

Dietary SBT by added prebiotic interactions were not significant $(\mathrm{P}>0.05)$ for digestibility coefficients of DM, $\mathrm{OM}, \mathrm{CP}, \mathrm{CF}, \mathrm{EE}$ or NFE examined in this study.

Table 2. Nutrients digestibility (\%) of 12-wk-old NZW rabbits as affected by dietary level of sugar beet tops (SBT) and prebiotic supplementation

\begin{tabular}{|c|c|c|c|c|c|c|}
\hline \multirow{2}{*}{ Treatments } & \multicolumn{6}{|c|}{ Nutrients digestibility (\%) } \\
\hline & $\overline{\mathrm{DM}}$ & $\mathrm{OM}$ & $\mathrm{CP}$ & $\mathrm{CF}$ & $\mathrm{EE}$ & NFE \\
\hline \multicolumn{7}{|l|}{$\overline{\text { SBT level }(A)}$} \\
\hline $0.00 \% \mathrm{~A} 1$ & $67.44^{\mathrm{b}}$ & $69.18^{\mathrm{b}}$ & $69.66^{\mathrm{b}}$ & $48.93^{\mathrm{b}}$ & $74.53^{\mathrm{b}}$ & $72.43^{b}$ \\
\hline $20.0 \% \mathrm{~A} 2$ & $68.79^{\mathrm{a}}$ & $71.14^{\mathrm{a}}$ & $71.06^{\mathrm{a}}$ & $50.89^{\mathrm{a}}$ & $76.60^{\mathrm{a}}$ & $74.25^{\mathrm{a}}$ \\
\hline $30.0 \% \mathrm{~A} 3$ & $69.37^{\mathrm{a}}$ & $71.04^{\mathrm{a}}$ & $70.69^{\mathrm{a}}$ & $51.10^{\mathrm{a}}$ & $76.43^{\mathrm{a}}$ & $74.20^{\mathrm{a}}$ \\
\hline SEM & 0.36 & 0.41 & 0.32 & 0.45 & 0.35 & 0.21 \\
\hline Significance & * & $*$ & $*$ & $*$ & $*$ & $*$ \\
\hline \multicolumn{7}{|l|}{ Prebiotic (B) } \\
\hline$(0.0 \mathrm{~g} / \mathrm{kg}) \mathrm{B} 1$ & $67.83^{\mathrm{b}}$ & $69.94^{\mathrm{b}}$ & $69.91^{\mathrm{b}}$ & $49.30^{\mathrm{b}}$ & $75.25^{\mathrm{b}}$ & $72.99^{b}$ \\
\hline$(1.0 \mathrm{~g} / \mathrm{kg}) \mathrm{B} 2$ & $69.23^{\mathrm{a}}$ & $70.96^{\mathrm{a}}$ & $71.03^{\mathrm{a}}$ & $51.31^{\mathrm{a}}$ & $76.45^{\mathrm{a}}$ & $74.26^{\mathrm{a}}$ \\
\hline SEM & 0.30 & 0.34 & 0.26 & 0.37 & 0.28 & 0.17 \\
\hline Significance & $*$ & $*$ & $*$ & $*$ & $*$ & $*$ \\
\hline \multicolumn{7}{|l|}{$A B$ Interaction } \\
\hline A1B1 & 65.76 & 67.28 & 67.88 & 46.61 & 72.79 & 70.45 \\
\hline A1B2 & 69.55 & 70.76 & 70.38 & 51.34 & 76.50 & 74.15 \\
\hline $\mathrm{A} 2 \mathrm{~B} 1$ & 68.56 & 71.23 & 70.85 & 50.43 & 76.60 & 74.27 \\
\hline $\mathrm{A} 2 \mathrm{~B} 2$ & 69.02 & 71.04 & 71.28 & 51.35 & 76.60 & 74.22 \\
\hline $\mathrm{A} 3 \mathrm{~B} 1$ & 69.18 & 71.33 & 71.00 & 50.86 & 76.36 & 74.24 \\
\hline A3B2 & 69.12 & 71.07 & 71.43 & 51.25 & 76.26 & 74.41 \\
\hline SEM & 0.51 & 0.58 & 0.45 & 0.64 & 0.49 & 0.30 \\
\hline$\underline{\text { Significance }}$ & NS & NS & NS & NS & NS & NS \\
\hline
\end{tabular}

Note. NS: Not significant. *: Significant at $\mathrm{P} \leq 0.05$. SEM $=$ Standard error of the means. a-b: Means in the same column bearing different superscripts are significantly different $(\mathrm{P} \leq 0.05)$. 


\subsection{Caecal Microbial Activity}

\subsubsection{Effects of Dietary SBT Level}

The effect of replacing dietary alfalfa hay with dried sugar beet tops (SBT) with or without a prebiotic on caecal fermentative activities and caecal microbial activity of growing rabbits are presented in Table 3 . These results showed that $\mathrm{pH}$ value, TVFA,s and NH3-N values for caecum content of 12 weeks old NZW rabbits were similar with no significant differences $(\mathrm{P} \geq 0.05)$ among different experimental groups. Apart from dietary prebiotic addition, it was observed that total bacterial (TBC), E. coli and lactobacillus counts were significantly affected (P $\leq$ 0.01 ) due to feeding the diets containing 20 or $30 \%$ SBT (50 or $75 \%$ replacement values of alfalfa hay) as compared to those of the control group ( $0 \% \mathrm{SBT})$. The principle site of fermentative activity in rabbits is the caecum, which characterized via the extensive variety of microbial flora community (Gouet \& Fonty, 1979), when the rabbit feed moving from milk to dry feed at three weeks of age; the microbial flora develops extensively (Ouhayoun, 1998), markedly affecting dietary, physiological, immunological and protecting strategies within the host animal (Gaskins, 1997). The type and stage of dietary fiber contribute to determine the quantity and diversity of caecal microbial network in the rabbit (Bennegadi et al., 2003).

Our effects agreed with the ones stated by (Robertson, 1988) who recorded lower microbial counts in caecal contents of rabbits fed diets with high lignin and insoluble non-starch polysaccharides fraction reduced through growing the digesta transit charge. Giant reductions in total anaerobic and coliforms counts within caecal samples from rabbits consumed eating regimen containing caprylic acid, which is brief-chain fatty acid (Skřivanová et al., 2010). Similarly, rabbits fed Phaseolus vulgaris straw (PS) containing various additives showed lower coliform count in their caecal content when compared with those fed the clover hay diet's (El-Gohary \& Abo El-Maaty, 2014). On the other hand, Oso et al. (2011), who recorded that lower microbial counts in caecal contents of rabbits fed with $300 \mathrm{~g} / \mathrm{kg}$ sorghum milling waste which could indicate the increased digesta transient rate caused by high dietary fiber.

\subsubsection{Effect of Prebiotic Supplementation}

Apart from dietary SBT level, added dietary prebiotic had a positive effect $(\mathrm{P} \leq 0.05 ; \mathrm{P} \leq 0.01)$ on caecal fermentative activities and caecal microbial activity of growing rabbits are given in Table 3 . The present $\mathrm{pH}$ value, ammonia-N (NH3-N) level, TBC, E.coli and lactobacills counts are the higher significant values at $(\mathrm{P} \leq 0.01)$ compared to control ones. The higher $\mathrm{pH}$ values of rabbits given prebiotic supplemented diets may be related to higher fermentation rate of microflora in the caecum. In the present study, no change was detected in concentrations of TVFA,s of growing NZW rabbits had fed prebiotic supplemented diets compeered with the control group.

These results agreed with those found by El-Gohary and Abo El-Maaty (2014) who found that prebiotics have clear and effective role in reducing total bacterial and coliforms counts and at the same time favoring the growth of Lactobacillus in the caeca. In agreement with this study, Xu et al. (2002) demonstrated that supplementation of $0.02 \%$ fructo-oligosaccharides increased Bifidobacterium and Lactobacillus in growing pigs. Fructo-oligosaccharides showed some protective effects against experimental inoculation of $E$. coli (Perez et al., 1995; Morisse et al., 1993), but in field conditions their positive effects on health have not been strongly demonstrated.

\subsubsection{The Interactions between Added Prebiotic and Dietary Level of SBT}

The SBT level by added prebiotic interactions increased significantly $(\mathrm{P} \leq 0.01)$ caecal microbial community for each of TBC with pronounced positive effects on lactobacillus populations, meanwhile E.coli counts showed significant reductions $(\mathrm{P} \leq 0.01)$. The perusal of these interactions may give an indication that both SBT and prebiotic addition exerted a positive effect in this respect. It was interesting to note that rabbits fed the basal diet plus prebiotic displayed higher TBC and lactobacillus counts and lower E. coli count as compared to those fed the basal diet alone. Similarly, feeding diets containing $20 \%$ or $30 \%$ SBT plus prebiotic caused positive effects on TBC, E. coli and lactobacillus counts compared with other experimental groups.

\subsection{Blood Plasma Components of Rabbits}

The effects of feeding diets containing 20 or $30 \%$ SBT to replace 50 or $75 \%$ of dietary alfalfa hay on blood plasma parameters of NZW rabbits are illustrated in Table 4. It was observed that feeding the SBT-containing diets did not alter plasma concentrations of urea and activities of AST, ALT and MDA of 84-day-old NZW growing rabbits compared with the basal diet group, irrespective of added dietary prebiotic. But rabbits fed diets containing SBT (20 and $30 \%)$ exhibited significantly higher $(\mathrm{P} \leq 0.05)$ blood plasma level of SOD than the control group. These results may indicate that replacement of dietary alfalfa hay with SBT up to $75 \%$ is safe and had useful effect on the 
metabolic functions or the health status of rabbits, since no morbidity or mortality were reported during the post-weaning period.

The absence of significant differences in most blood plasma parameters of rabbits, observed in the present work, in harmony with the findings of Galal et al. (2014), who reported that replacing dietary clover hay with dried strawberry vines did not significantly affect the plasma concentrations of total protein, albumin, globulin, glucose, total lipids, cholesterol or creatinine. Although, El-Gohary and Abo El-Maaty (2014), who found that replacing the clover hay in rabbit diets with Phaseolus vulgaris straw had no significant effect on blood plasma substances.

The results summarized in Table 4 indicated that dietary supplementation with prebiotic caused significant increases $(\mathrm{P} \leq 0.05)$ in blood plasma activities of SOD of rabbits. But, plasma levels of Urea, liver enzyme activities (AST, ALT) and MDA concentration had no significant effect $(\mathrm{P}>0.05)$ due to treatments and significance decreases in plasma creatinine, regardless of dietary SBT level. This results was still within normal range as indicated by the non-sign of toxicity were noted.

The lack of a significant effect of dietary prebiotic inclusion on most blood plasma parameters of rabbits, noticed in this work, is in through with the results reported by El-Gohary and Abo El-Maaty (2014), who found that blood plasma constituents of rabbits were not influenced by feeding prebiotic-supplement ration. Apart from the effect of dietary tested material, the noted means of blood constituents of weaning rabbits in the present work fell within the normal physiological range (Özkan et al., 2012). The interactions between added prebiotic and dietary level of SBT were not significant for all blood plasma parameters measured in this study.

\subsection{Histological Observations}

\subsubsection{Liver Histology}

The liver structure of rabbits, as in different mammalian species, is divided into many hepatic lobules; each consists of radially-arranged cords of hepatocytes extended from the central vein to the periphery of the lobule. The histological examination of liver sections from rabbits that fed the control diet (Figure 1) showed normal hepatic structure except a few fatty cirrhotic areas and infiltrable fluids. This was also observed in the liver sections from rabbits that fed $20 \%$ or $30 \%$ sugar beet tops (Figures 2 and 3), where there is marked hypertrophy of liver cells accompanied with many kuepffer cells, infiltrable fluids and large bile duct (Figure 3). A similar structure was also observed when rabbits were fed $30 \%$ sugar beet tops, although the central vein was slightly dilated. Prebiotic addition to the control diet improved liver histological structure (Figure 4) where normal central vein along with few fatty cirrhotic areas could be seen. Moreover, liver sections from rabbits that fed $20 \%$ sugar beet plus prebiotic (Figure 5) and $30 \%$ Sugar beet plus prebiotic showed several changes. There were necrotic areas, dilated central veins with disrupted hepatic cords and many fatty cirrhotic areas. There are also many infiltrale fluids in between the hepatic cards (Figure 6). In general, the previous changes in liver histology in response to sugar beet feeding either with or without prebiotic, did not cause any side effects on liver function. It is likely that these changes might be related to the hyperactivity of liver tissue, as liver is the main metabolic organ, and this may cause some metabolic, but not pathologic-disorders, to liver tissues. On the other hand, all sections showed the presence of Kupffer cells with their numbers markedly increased in the control and sugar beet tops sections (Figures 1,2 and 3). These cells act as an effective particulate filtration system in liver tissues to prevent any pathogenic bacteria or other particulate matters from the digestive system to pass from the portal blood into the systemic circulation. In this concern, many worldwide studies support the idea that many plants and herbs contain phytochemicals which could be used to protect hepatocytes from degeneration and enhance antioxidant status of different mammalian species, hence improving productive performance (Middleton et al., 2000; Nakatani, 2003; Chrpova et al., 2010). 
Table 3. Caecal microbial activity of 12-wk-old NZW rabbits as affected by dietary level of sugar beet tops (SBT) and prebiotic supplementation

\begin{tabular}{|c|c|c|c|c|c|c|}
\hline \multirow[b]{2}{*}{ Treatments } & \multicolumn{3}{|c|}{ Caecal fermentative activities } & \multicolumn{3}{|c|}{ Caecal microbial activity } \\
\hline & $\mathrm{pH}$ value & $\begin{array}{l}\mathrm{NH}_{3}-\mathrm{N} \\
(\mathrm{mg} / 100 \mathrm{dL})\end{array}$ & $\begin{array}{l}\text { TVFA,s } \\
(\mathrm{mmol} / 100 \mathrm{ml})\end{array}$ & $\mathrm{TBC}$ & $\begin{array}{l}\text { E. coli } \\
\text { count }\end{array}$ & $\begin{array}{l}\text { Lactobacillus } \\
\text { count }\end{array}$ \\
\hline \multicolumn{7}{|l|}{$\overline{\text { SBT level }(A)}$} \\
\hline $0.00 \% \mathrm{~A} 1$ & 7.020 & 0.317 & 6.262 & $12.915^{\mathrm{b}}$ & $3.620^{\mathrm{a}}$ & $7.440^{\mathrm{b}}$ \\
\hline $20.0 \% \mathrm{~A} 2$ & 6.985 & 0.290 & 6.263 & $13.50^{\mathrm{a}}$ & $3.313^{\mathrm{b}}$ & $8.938^{\mathrm{a}}$ \\
\hline $30.0 \% \mathrm{~A} 3$ & 6.929 & 0.353 & 6.265 & $13.07^{\mathrm{a}}$ & $3.103^{\mathrm{b}}$ & $8.582^{\mathrm{a}}$ \\
\hline SEM & 0.033 & 0.013 & 0.036 & 0.137 & 0.061 & 0.099 \\
\hline Significance & NS & NS & NS & $*$ & $* *$ & $* *$ \\
\hline \multicolumn{7}{|l|}{ Prebiotic (B) } \\
\hline$(0.0 \mathrm{~g} / \mathrm{kg}) \mathrm{B} 1$ & 6.951 & $0.336^{\mathrm{a}}$ & 6.284 & $12.209^{\mathrm{b}}$ & $4.638^{\mathrm{a}}$ & $7.158^{\mathrm{b}}$ \\
\hline$(1.0 \mathrm{~g} / \mathrm{kg}) \mathrm{B} 2$ & 7.005 & $0.304^{\mathrm{b}}$ & 6.242 & $14.114^{\mathrm{a}}$ & $2.053^{\mathrm{b}}$ & $9.482^{\mathrm{a}}$ \\
\hline SEM & 0.027 & 0.011 & 0.029 & 0.111 & 0.049 & 0.080 \\
\hline Significance & NS & $*$ & NS & $*$ & $* *$ & $* *$ \\
\hline \multicolumn{7}{|l|}{$A B$ Interaction } \\
\hline A1B1 & 7.065 & 0.312 & 6.290 & 12.207 & 5.023 & 6.473 \\
\hline A1B2 & 6.975 & 0.322 & 6.233 & 13.623 & 2.216 & 8.407 \\
\hline $\mathrm{A} 2 \mathrm{~B} 1$ & 6.985 & 0.278 & 6.263 & 12.687 & 4.613 & 7.963 \\
\hline $\mathrm{A} 2 \mathrm{~B} 2$ & 6.985 & 0.302 & 6.263 & 14.313 & 2.013 & 9.913 \\
\hline A3B1 & 6.802 & 0.418 & 6.300 & 11.733 & 4.277 & 7.037 \\
\hline A3B2 & 7.055 & 0.288 & 6.230 & 14.407 & 1.930 & 10.127 \\
\hline SEM & 0.047 & 0.019 & 0.051 & 0.193 & 0.087 & 0.139 \\
\hline Significance & NS & NS & NS & $* *$ & $* *$ & $* *$ \\
\hline
\end{tabular}

Note. NS: Not significant. *: Significant at $\mathrm{P} \leq 0.05 .{ }^{* *}$ : Significant at $\mathrm{P} \leq 0.01 . \mathrm{SEM}=$ Standard error of the means. a-b: Means in the same column bearing different superscripts are significantly different $(\mathrm{P} \leq 0.05)$.

Table 4. Blood plasma constituents of 84 day-old NZW rabbits as affected by dietary level of sugar beet tops (SBT) and prebiotic

\begin{tabular}{|c|c|c|c|c|c|c|}
\hline Treatments & $\begin{array}{l}\text { Creatinine } \\
(\mathrm{mg} / 100 \mathrm{ml})\end{array}$ & $\begin{array}{l}\text { Urea } \\
(\mathrm{g} / \mathrm{dL})\end{array}$ & $\begin{array}{l}\mathrm{AST} \\
(\mathrm{U} / \mathrm{L})\end{array}$ & $\begin{array}{l}\text { ALT } \\
(\mathrm{U} / \mathrm{L})\end{array}$ & $\begin{array}{l}\text { MDA } \\
(\mu \mathrm{mol} / \mathrm{ml})\end{array}$ & $\begin{array}{l}\text { SOD } \\
(\mathrm{U} / \mathrm{ml})\end{array}$ \\
\hline \multicolumn{7}{|l|}{ SBT level $(A)$} \\
\hline $0.00 \% \mathrm{~A} 1$ & $1.180^{\mathrm{a}}$ & 11.70 & 41.50 & 14.07 & 27.25 & $49.82^{\mathrm{b}}$ \\
\hline $20.0 \% \mathrm{~A} 2$ & $1.007^{\mathrm{b}}$ & 11.73 & 44.28 & 14.75 & 27.47 & $53.08^{\mathrm{a}}$ \\
\hline $30.0 \% \mathrm{~A} 3$ & $1.002^{\mathrm{b}}$ & 11.63 & 41.40 & 14.08 & 23.90 & $52.95^{\mathrm{a}}$ \\
\hline SEM & 0.016 & 0.60 & 1.33 & 0.48 & 2.03 & 0.80 \\
\hline Significance & $*$ & NS & NS & NS & NS & $*$ \\
\hline \multicolumn{7}{|l|}{ Prebiotic (B) } \\
\hline$(0.0 \mathrm{~g} / \mathrm{kg}) \mathrm{B} 1$ & $1.117^{\mathrm{a}}$ & 11.51 & 42.71 & 14.09 & 25.79 & $46.72^{\mathrm{b}}$ \\
\hline$(1.0 \mathrm{~g} / \mathrm{kg}) \mathrm{B} 2$ & $1.009^{\mathrm{b}}$ & 11.87 & 42.08 & 14.51 & 26.62 & $57.18^{\mathrm{a}}$ \\
\hline SEM & 0.013 & 0.49 & 1.09 & 0.39 & 1.66 & 0.65 \\
\hline Significance & $*$ & NS & NS & NS & NS & $*$ \\
\hline \multicolumn{7}{|l|}{$A B$ Interaction } \\
\hline A1B1 & 1.220 & 11.60 & 40.83 & 13.40 & 27.33 & 45.87 \\
\hline A1B2 & 1.140 & 11.80 & 42.17 & 14.73 & 27.17 & 53.77 \\
\hline A2B1 & 1.067 & 10.97 & 44.43 & 14.27 & 26.77 & 47.27 \\
\hline $\mathrm{A} 2 \mathrm{~B} 2$ & 0.947 & 12.50 & 44.13 & 15.23 & 28.17 & 58.90 \\
\hline A3B1 & 1.063 & 11.97 & 42.87 & 14.60 & 23.27 & 47.03 \\
\hline A3B2 & 0.940 & 11.30 & 39.93 & 13.57 & 24.53 & 58.87 \\
\hline SEM & 0.023 & 0.85 & 1.88 & 0.68 & 2.87 & 1.12 \\
\hline Significance & NS & NS & NS & NS & NS & NS \\
\hline
\end{tabular}

Note. NS: Not significant. *: Significant at $\mathrm{P} \leq 0.05$. SEM $=$ Standard error of the means. a-b: Means in the same column bearing different superscripts are significantly different $(\mathrm{P} \leq 0.05)$. 


\subsubsection{Ileum Histology}

Histopathological examination of ileum sections of rabbits as influenced by different dietary treatments is illustrated in Figures 7 to 12. It is clear from these sections that there are great variations in the height and width of the intestinal villi, accompanied by changes in muscularis mucosa layer. In the control group (Figure 7) section, the villi was tall but with small diameter and little goblet cells in the epithelial surface. However, the villi size and number per microscopic field area were greatly increased in all treatment sections especially those of T5 and T6 treatments (Figures 11 and 12). There are many crypts in the base of villi differing in size and number located over the sub-mucosal layer within the lamina propria, in which many blood, lymph and nerve supplies are present. These crypts are the most abundant tubular glands in all sections especially in Figure 8 (T2); Figure 11 (T5) and Figure 12 (T6), compared with the control group sections. It is worth noting that the number and size of Brunner's glands in the lamina propria of the villi were also increased in treatment sections than the control ones. These glands are located beside the crypts and have similar histological appearance but with many goblet cells in their epithelial lining (Culling, 1983). Since, these glands along with the crypts were known to secrete mucus in response to direct stimuli of digesta in the ileum or intestinal hormones, especially secretin (Gallois et al., 2004). The function of mucus secreted by Brunner's glands is to protect the intestinal wall from digestion by the gastric juice. Mucus is also secreted in large quantities by goblet cells located intensively in the epithelial surface cells of the villi and crypts. The crypts fluids are almost pure extracellular fluid with a neutral $\mathrm{pH}$ in the range of 6.5 to 7.5 . These secretions, in general, may help improvements in the productive performance. These histological observations suggest that using sugar beet with prebiotic could enhance the histological structure of the digestive system in growing rabbits. This is in accordance with many findings by Roberfroid (2000) and Pelicano et al. (2005) in broilers and Mourão et al. (2006) in growing rabbits.

Table 5. Histology (Histomorphometric measurements of ileum of growing NZW rabbits as affected by dietary level of sugar beet tops (SBT) and prebiotic supplementation from 6 to 12 weeks of age

\begin{tabular}{llll}
\hline Variable treatment & Villus height (um)* & Crypt depth (um) & VH:CD \\
\hline T1 (control) & $572.3^{\mathrm{d}}$ & $116.4^{\mathrm{b}}$ & $4.92^{\mathrm{d}}$ \\
T2 (20\% SBT) & $682.8^{\mathrm{b}}$ & $125.8^{\mathrm{a}}$ & $5.46^{\mathrm{c}}$ \\
T3 (30\% SBT) & $698.4^{\mathrm{b}}$ & $107.5^{\mathrm{c}}$ & $6.52^{\mathrm{b}}$ \\
T4 (control+Pre.) & $635.6^{\mathrm{c}}$ & $112.2^{\mathrm{b}}$ & $5.65^{\mathrm{c}}$ \\
T5 (20\% SBT+Pre.) & $714.4^{\mathrm{b}}$ & $98.6^{\mathrm{c}}$ & $7.26^{\mathrm{a}}$ \\
T6 (30\% SBT+Pre.) & $742.2^{\mathrm{a}}$ & $104.5^{\mathrm{c}}$ & $7.13^{\mathrm{a}}$ \\
SEM & 46.54 & 8.82 & 1.08 \\
\hline
\end{tabular}

Note. ${ }^{*} \mathrm{n}=10$ microscopic fields. 


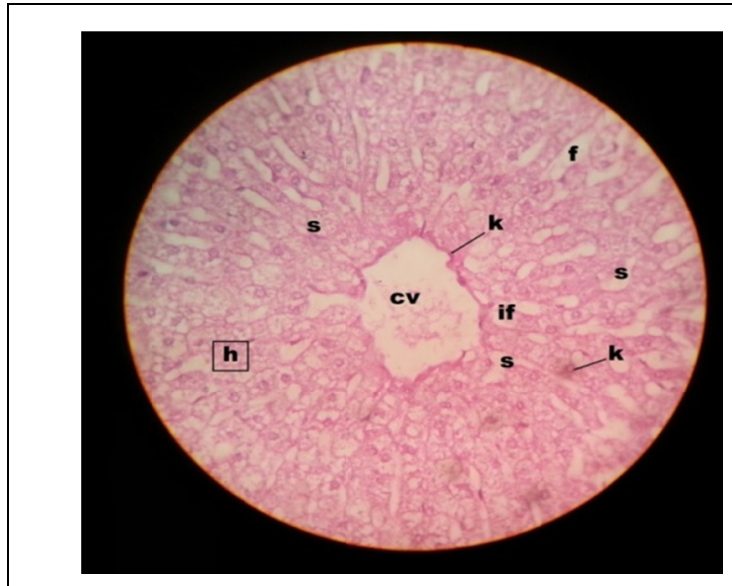

Figure 1. T.S. through liver from rabbits of the control (T1) group $(\mathrm{H} \& \mathrm{E} \times 40)$

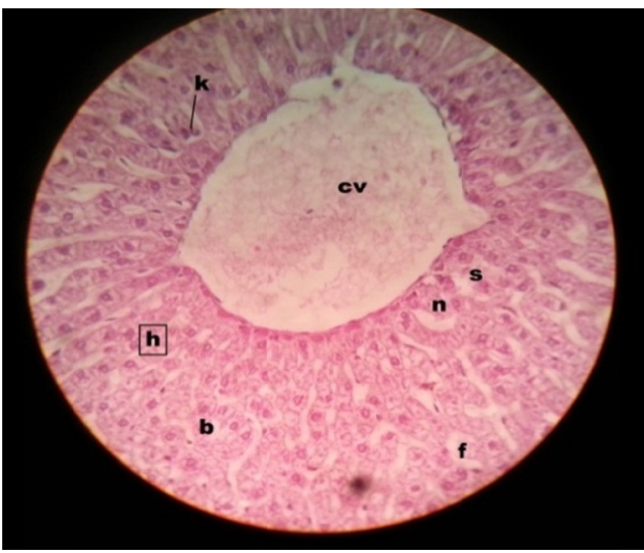

Figure 3. T.S. through liver from rabbits fed the $30 \%$ sugar beet tops (T3) group (H \& E × 40)

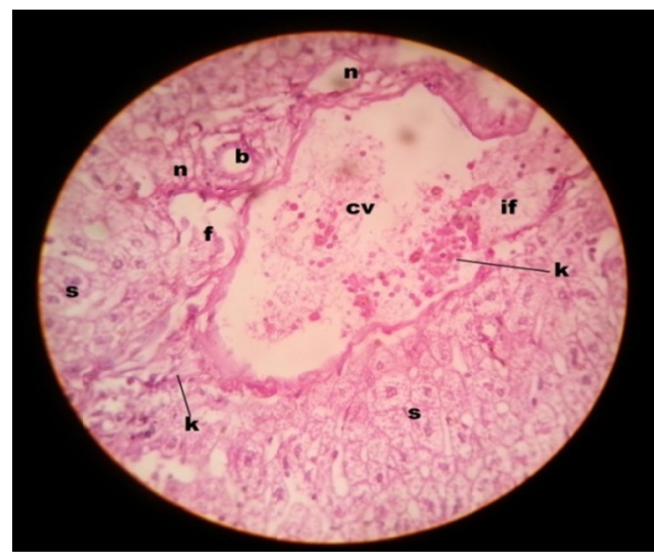

Figure 5. T.S. through liver from rabbits fed the $20 \%$ sugar beet tops + prebiotic (T5) group ( $\mathrm{H} \& \mathrm{E} \times 40)$

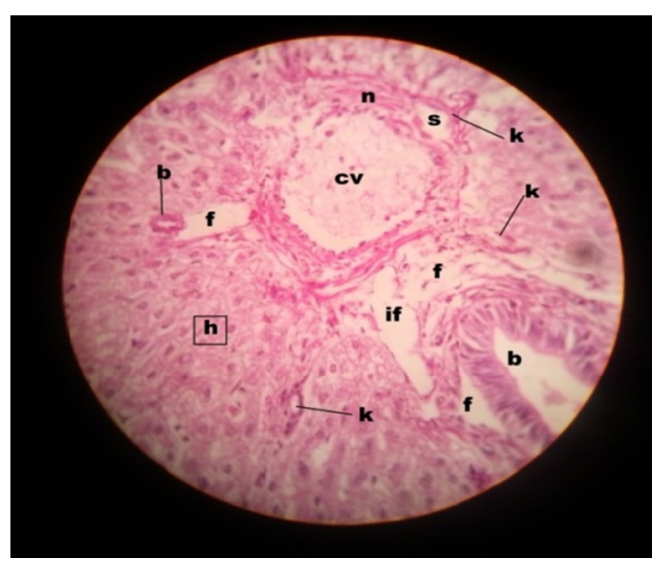

Figure 2. T.S. through liver from rabbits fed the $20 \%$ sugar beet tops (T2) group (H \& E $\times 40)$

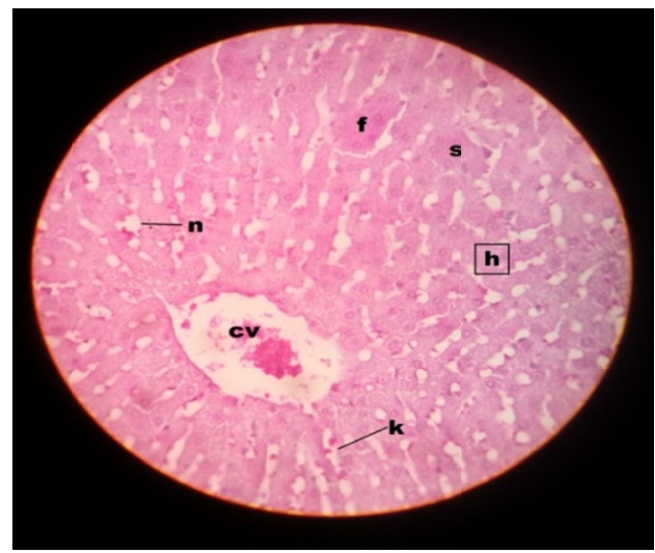

Figure 4. T.S. through liver from rabbits fed the control + prebiotic (T4) group $(\mathrm{H} \& \mathrm{E} \times 40)$

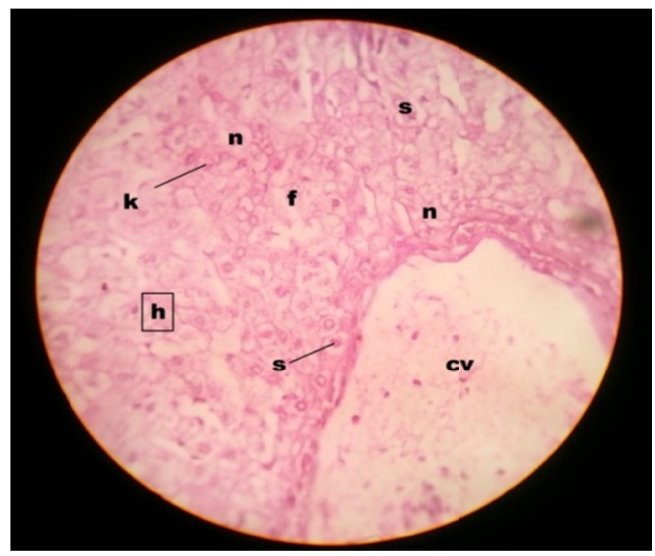

Figure 6. T.S. through liver from rabbits fed the $20 \%$ sugar beet tops + prebiotic (T6) group (H \& E $\times 40)$

Note. Abbreviation key of liver sections: $\mathrm{Cv}=$ central vein; $\mathrm{h}=$ hepatocytes; $\mathrm{s}=$ blood sinusoids; if $=$ infiltrable fluids; $\mathrm{k}=$ küpffercells; $\mathrm{b}=$ bile duct; $\mathrm{n}=$ necrotic area; $\mathrm{f}=$ fatty cirrhotic area. 


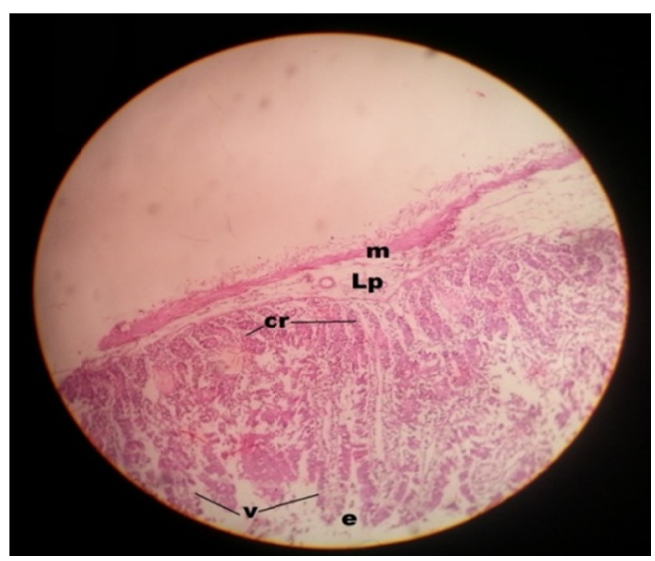

Figure 7. T.S. through the wall of ileum from rabbits of the control (T1) group $(\mathrm{H} \& \mathrm{E} \times 10)$

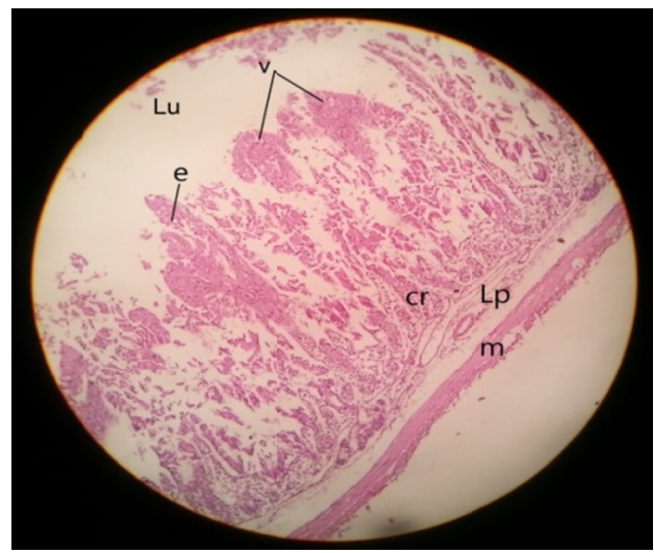

Figure 9. T.S. through the wall of ileum from rabbits fed the $30 \%$ sugar beet tops (T3) group ( $\mathrm{H} \& \mathrm{E} \times 10)$

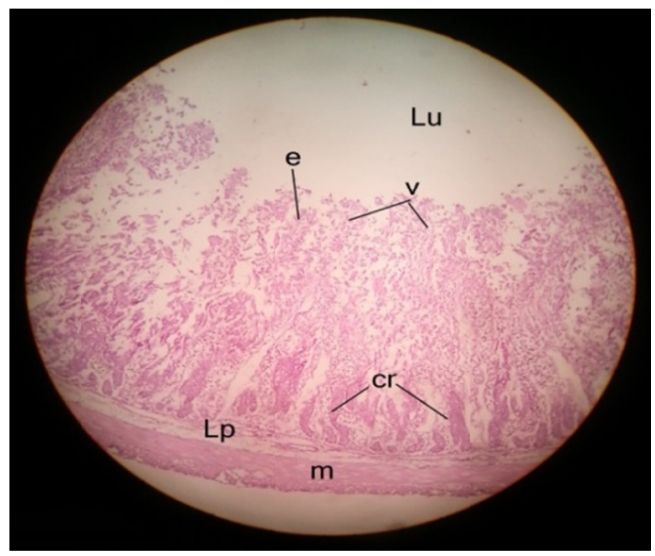

Figure 11. T.S. through the wall of ileum from rabbits fed the $20 \%$ sugar beet tops + prebiotic (T5) group (H $\& \mathrm{E} \times 10)$

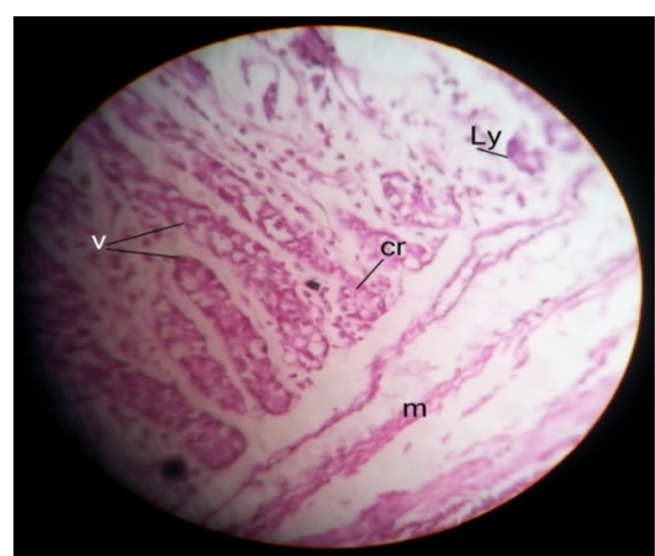

Figure 8. T.S. through the wall of ileum from rabbits fed the $20 \%$ sugar beet tops (T2) group ( $\mathrm{H} \& \mathrm{E} \times 10)$

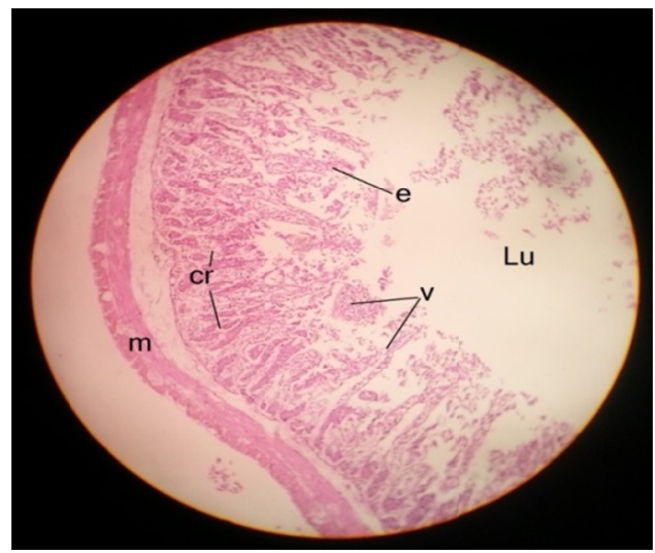

Figure 10. T.S. through the wall of ileum from rabbits fed the control + prebiotic (T4) group $(\mathrm{H} \& \mathrm{E} \times 10)$

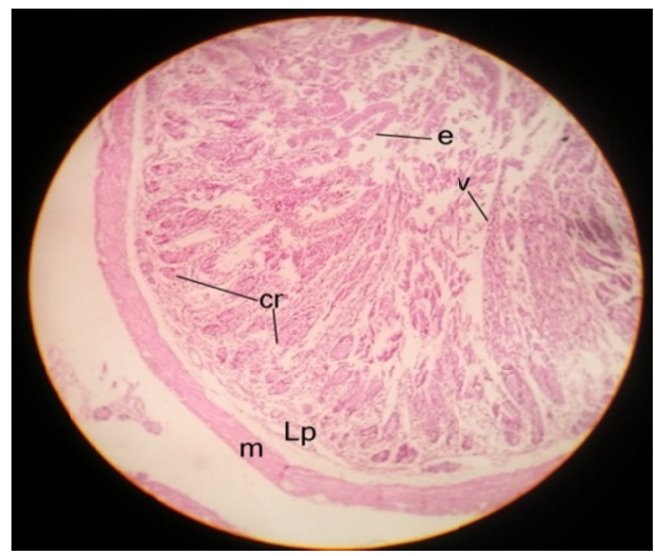

Figure 12. T.S. through the wall of ileum from rabbits fed the $30 \%$ sugar beet tops + prebiotic (T6) group (H $\& \mathrm{E} \times 10$ )

Note. Abbreviation key: $\mathrm{m}=$ muscularis mucosa; $\mathrm{cr}=$ crypts of Lieberkühn; $\mathrm{v}=$ villi; $\mathrm{Lp}=$ lamina propria; $\mathrm{e}=$ epithelial lining; $\mathrm{Lu}=$ lumen. 


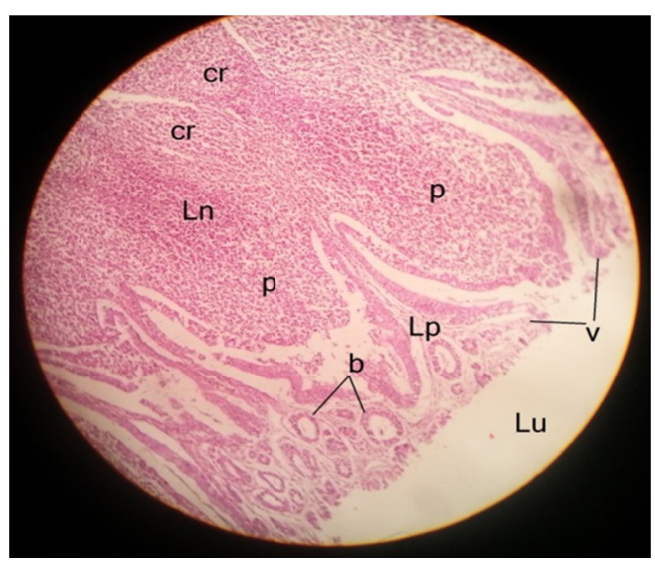

Figure 13. T.S. through the wall of cecum from rabbits fed the control (T1) group $(\mathrm{H} \& \mathrm{E} \times 10)$

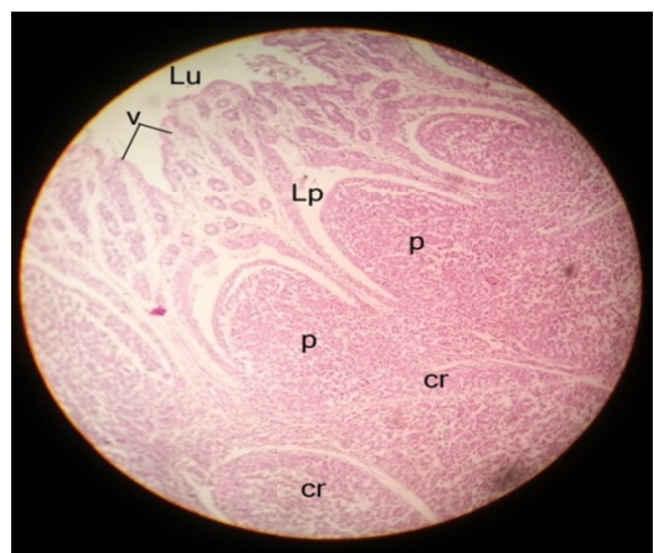

Figure 15. T.S. through the wall of cecum from rabbits fed the $30 \%$ sugar beet tops (T3) group (H \& $\mathrm{E} \times 10$ )

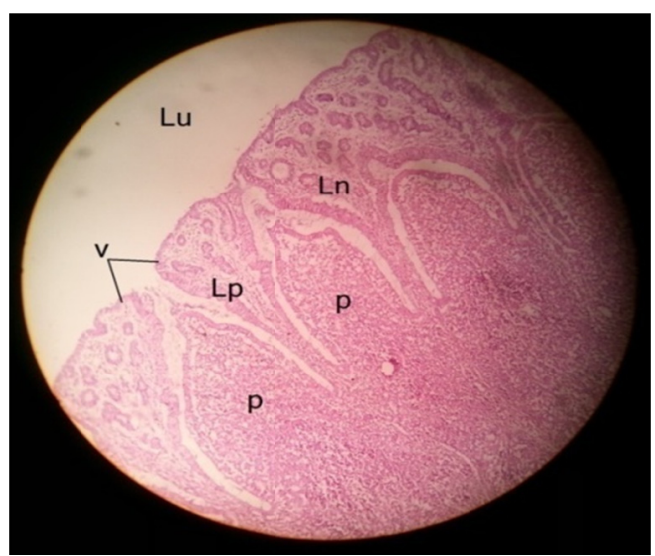

Figure 17. T.S. through the wall of cecum from rabbits of $20 \%$ sugar beet tops + prebiotic (T5) group $(\mathrm{H} \& \mathrm{E} \times 10)$

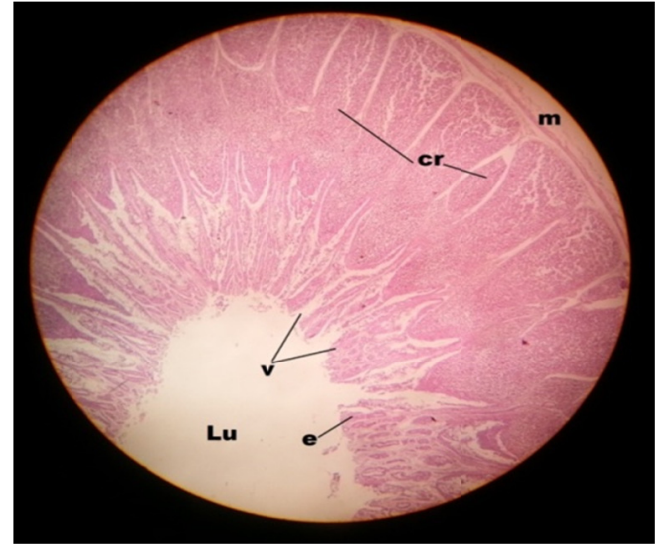

Figure 14. T.S. through the wall of cecum from rabbits fed the $20 \%$ sugar beet tops (T2) group (H \& $\mathrm{E} \times 10$ )

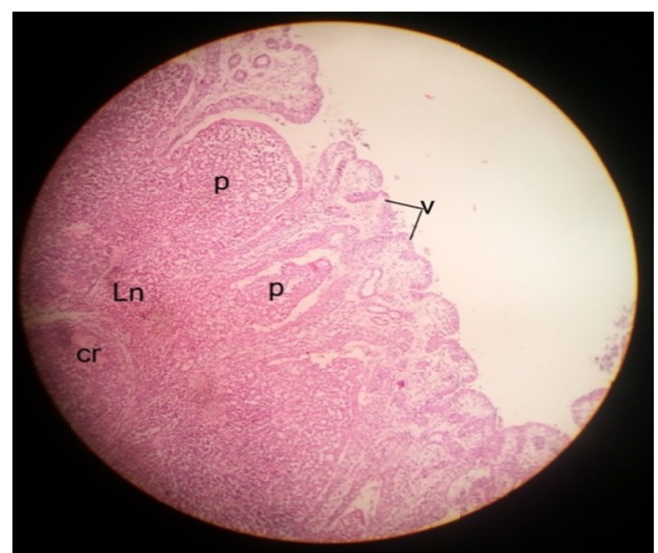

Figure 16. T.S. through the wall of cecum from rabbits fed the control + prebiotic (T4) group (H \& E $\times 10$ )

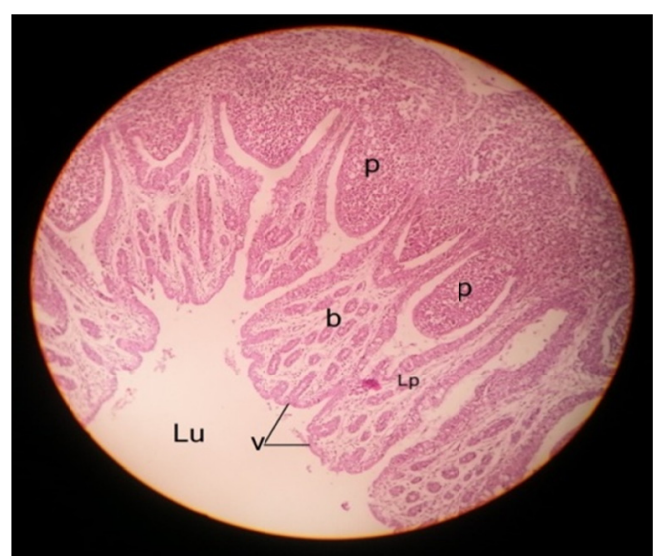

Figure 18. T.S. through the wall of cecum from rabbits fed the $30 \%$ sugar beet tops + prebiotic (T6) group $(\mathrm{H} \& \mathrm{E} \times 10)$

Note. Abbreviation key: $\mathrm{V}=$ villi $\mathrm{P}=$ plicae; $\mathrm{Ln}=$ lymph node; $\mathrm{Lu}=$ lumen; $\mathrm{cr}=$ crypts; $\mathrm{b}=$ blood vessels; $\mathrm{Lp}=$ lamina propria; $\mathrm{m}=$ musclaris mucosa. 


\subsubsection{Caecal Histology}

In general the caecal wall of growing rabbits is comparable with that of the other intestinal segments; however, there are many special changes specific to cecum histology. Among these changes, the muscularis mucosa layer is not well-developed but contains outer longitudinal and inner circular muscles which strengthen the caecal wall. It is clear from caecal sections that the villi are well arranged in many plicae with different shapes and size of villi especially in the sections from growing rabbits group that fed 30\% SBT (T3; Figure 15); growing rabbits group that fed 20\% SBT with prebiotics (T5; Figure 17) and growing rabbits group fed 30\% SBT with prebiotics group (T6; Figure 18), respectively. The crypts are short and small tubular glands opened in between the villi and occupy most of the lamina propria layer between the bases of the villi and the muscularis mucosa. There is also many diffuse and nodular accumulation of lymphoid cells appeared as lymph nodes and/or nodules accompanied with blood vessels and nerves. It is difficult to attribute these histological changes to the dietary treatments, however, the muscular is layer and the shape and size of the villi with their mucosal epithelium lining in the sugar beet plus prebiotic fed rabbits may support the possible influence of treatments on caecal fermentation activity, volatile fatty acids production, decreased $\mathrm{pH}$ value and bacterial ecosystem in the cecum, which may also explain the positive impacts of prebiotics and sugar beet on performance of growing NZW rabbits. In this respect Caspary (1992) indicated that increasing villus height may reflect greater surface area and more nutrients absorption. Also, Abdel-Khalek et al. (2011) reported that the depth of caecum mucosa is important for increasing the absorption of microbial products. It is well known that the crypts of lieberklihn are considered as the villlus factory, thus, deeper crypts reflect fast tissue turnover for renewability of villi in response to different treatments. This was supported by the findings by Samanya and Yamauchi (2002) who used dried Bacillus bacteria in chickens diet, and Rao and Samak (2012) who studied the role of glutamine in the protection of epithelial lining of different intestinal walls. These findings support our results, where the crypts occupy most of the lamina propria layer, especially in sections from rabbits fed SBT plus prebiotic enriched diets. Similar observations were also reported by El-Badawi et al. (2017) who used different levels of moringa leaves in rabbit nutrition.

Table 6. Histology (Histomorphometric) measurements of caecum of growing NZW rabbits as affected by dietary level of sugar beet tops (SBT) and prebiotic from 6 to 12 weeks of age

\begin{tabular}{llll}
\hline Variable treatment & Villus height (um)* & Crypt depth (um) & VH:CD \\
\hline T1 (control) & $155.4^{\mathrm{d}}$ & $84.3^{\mathrm{b}}$ & $1.84^{\mathrm{c}}$ \\
T2 (20\% SBT) & $188.6^{\mathrm{b}}$ & $90.2^{\mathrm{ab}}$ & $2.02^{\mathrm{b}}$ \\
T3 (30\% SBT) & $194.2^{\mathrm{b}}$ & $88.6^{\mathrm{b}}$ & $2.18^{\mathrm{b}}$ \\
T4 (control+Pre.) & $170.6^{\mathrm{c}}$ & $95.4^{\mathrm{a}}$ & $1.77^{\mathrm{c}}$ \\
T5 (20\% SBT+Pre.) & $206.5^{\mathrm{b}}$ & $89.4^{\mathrm{b}}$ & $2.30^{\mathrm{b}}$ \\
T6 (30\% SBT+Pre.) & $224.1^{\mathrm{a}}$ & $85.2^{\mathrm{b}}$ & $2.62^{\mathrm{a}}$ \\
SEM & 19.36 & 6.15 & 0.90 \\
\hline
\end{tabular}

Note. ${ }^{*} \mathrm{n}=10$ microscopic fields.

\section{References}

Abdel-Hady, D. H., \& El-Abasy, M. A. (2015). Effect of prebiotic and probiotic on growth, immuno-hematological responses and biochemical parameters of infected rabbits with Pasteurella multocida. Benha Vet. Med. J., 28(2), 40-51.

Abdel-Khalek, A. E., Kalaba, Z. M., \& El-gogary, M. R. (2011). Functional, anatomical and histological development of caecum in rabbits. Curren Research in poultry Science, I, 54-65. https://doi.org/10.3923/ crpsj.2011

Abo El-Maaty, H. M. A., Sherif, S. Kh., \& Foda, L. S. A. (2017). Efficiency of Utilization of Sugar Beet Tops Hay and Prebiotic in Diets of Growing Rabbits. Asian Journal of Animal and Veterinary Advances, 12, 71-79. https://doi.org/10.3923/ajava.2017.71.79

Allain, C. C., Poon, L. S., Chan, C. S. G., Richmond, W., \& Fu, P. C. (1974). Enzymatic determination of total serum cholesterol. Clinical Chemistry, 20(4), 470-475.

AOAC (Association of Official Analytical Chemists). (2000). Official Methods of Analysis (17th ed.). Washington, DC. 
Attia, Y. A., Hamed, R. S., Abd El-Hamid, A. E., Al-Harthi, M. A., Shahba, H. A., \& Bovera, F. (2015). Performance, blood profile, carcass and meat traits and tissue morphology in growing rabbits fed mannanoligosaccharides and zinc-bacitracin continuously or intermittently. Animal Science Papers and Reports, 33(1), 85-101.

Bennegadi, N., Fonty, G., Miller, L., Gidenne, T., \& Licois, D. (2003). Effects of Age and Dietary Fiber Level on Caecal Microbial Communities of Conventional and Specific Pathogen-Free Rabbits. Microbiology and Ecology Health Disease, 5, 23-32. https://doi.org/10.1080/08910600310015574

Carabaño, R., García, J., \& de Blas, J. C. (2001). Effect of fibre source on ileal apparent digestibility of non-starch polysaccharides in rabbits. Anim. Sci., 72, 343-350.

Caspary, W. F. (1992). Physiology and Pathophysiology of intestinal absorption. The American J. of Clin. Nutri., 55(Suppl. 10), 2995-3085. https://doi.org/10.1093/ajcn/55.1.299s

Chrpova, D., Kourimska, L., Gordon, M. H., Hermanova, V., Roubickova, I., \& Panek, J. (2010). Antioxidant activity of selected phenols and herbs used in diets for medical conditions. Czech. J. Food Sci., 28(4), 317-325.

Culling, C. F. (1983). Handbook of histopathological and histochemical techniques (3rd ed.). Butterworth, London.

Daader, A. H., \& Seleem, T. S. T. (1999). Recent trends in rabbit production. 1st International Conference on Indigenous Acclimatized Rabbits, El-Arish-North Sinai, Egypt.

Doumas, B. T., Bayse, D. D., Carter, R. J., Peters, T., \& Schaffer, R. (1981). A candidate reference method for determination of total protein in serum: Development and validation. Clinical Chemistry, 27(10), 1642-1650.

Doumas, B. T., Watson, W. A., \& Biggs, H. G. (1971). Albumin standards and the measurement of serum albumin with bromocresol green. Clin. Chim. Acta, 31, 87-96. http://dx.doi.org/10.1016/0009-8981(71)90365-2

Duncan, D. B. (1955). Multiple range and multiple F tests. Biometrics, 11, 1-42. https://doi.org/10.2307/3001478

El-Badawi, A. Y., El-Wardany, I., Abd El-Moez, S. I., Helal, F. I. S., Ali, N. G. M., Shourrap, M. I., \& Aboelazab, O. M. (2017). Impact of dietary moringa oleifera leaves on intestinal pathogenic load and histological structure of growing rabbits raised under heat stress conditions. Animal Production Science. https://doi.org/10.1071/AN16540

El-Gohary, F. A., \& Abo El-Maaty, H. M. A. (2014). Phaseolus vulgaris straw as a substitute for clover hay in rabbit diets with prebiotic supplementation and feed restriction interaction: Influence on nutrient utilization, caecal activity, carcass yield and blood plasma constituents. Global Veterinaria, 13(6), 1010-1021. https://doi.org/10.5829/idosi.gv.2014.13.06.9162

El-Kerdawy, D. M. A. (1997). Olive pulp as a new energy source for growing rabbits. Egyption Journal of Rabbits Science, 7(1), 1-12.

Fossati, P., \& Prencipe, L. (1982). Serum triglycerides determined colorimetrically with an enzyme that produces hydrogen peroxide. Clinical Chemistry, 28(10), 2077-2080.

Friedewald, W. T., Levy, R. I., \& Fredrickson, D. S. (1972). Estimation of the concentration of low-density lipoprotein cholesterol in plasma, without use of the preparative ultracentrifuge. Clinical Chemistry, 18(6), 499-502.

Gaafar, H. M. A., Abd El-Lateif, A. I. A., \& Abd El-Hady, S. B. (2014). Effect of partial replacement of berseem hay by ensiled and dried sweet potato vines on performance of growing rabbits. Report and Opinion, 6(8), 60-66.

Gaafar, H. M. A., Abd El-Lateif, A. I. A., \& Abd El-Hady, S. B. (2010). Effect of partial replacement of berseem hay by ensiled and dried sugar beet tops on performance of growing rabbits. Researcher, 2(9), 10-15. https://doi.org/10.7537/marsrsj020910.02

Galal, H. M. F., ElMenniawy, M. A., Abo-Fadel, M. H., Khi, A. A., \& Abdel-Azeam, S. N. (2014). Some nutritional studies on using strawberry (Fragaria $\times$ Ananas) vine as hay in rabbit ration. J. Anim. Poultry Prod., 5(12), 635-647.

Gallois, M., Gidenne, T., Fortun-Lamothe, L., Huerou-Luron, I. L., \& Lalles, J. P. (2004). Weaning age and development of the small intestinal mucosa in the young rabbit. Proceedings $8^{\text {th }}$ world Rabbit Congerss, world Rabbit Science Association, Puebla, Mexico (pp. 1079-1085). 
Gaskins, H. (1997). Immunological aspects of host/microbiota interactions at the intestinal epithelium. Gastrointestinal Microbiology, 2, 537-587. https://doi.org/10.1007/978-1-4757-0322-1_14

Gidenne, T. (1995). Effect of fibre level reduction and glucooligosaccharide addition on the growth performance and caecal fermentation in the growing rabbit. Anim. Feed Sci. Techn., 56, 253-263. https://doi.org/ 10.1016/0377-8401(95)008349

Gidenne, T. (2003). Fibres in rabbit feeding for digestive troubles prevention: Respective role of low-digested and digestible fiber. Livest. Prod. Sci., 81, 105-117. https://doi.org/10.1016/S0301-6226(02)00301-9

Gouet, P., \& Fonty G. (1979). Changes in the digestive microflora of holoxenic rabbits from birth until adulthood. Ann. Biol. Anim. Bioch. Biophys., 19, 553-566. https://doi.org/10.1051/rnd:19790501

Hussien, F. (2009). Nutritional evaluation of some vegetable crops wastes used in rabbits feeding (PhD Thesis, Fac. Agric., Cairo Univ., Egypt).

Junqueira, L. C., Toledo, O. M., \& Montes, G. S. (1981). Correlation of specific sulfated glycosaminoglycans with collagen types I, II and III. Cell Tissue Res., 217, 171-175. https://doi.org/10.1007/BF00233835

Knarreborge, A., Miquel, N., Granli, T., \& Jensen, B. B. (2002). Establishment and application of an in vitro methodology to study the effects of organic acids on coliform and lactic acid bacteria in the proximal part of the gastrointestinal tract of piglets. Anim. Feed Sci. Technol., 99, 131-140. https://doi.org/10.1016/ S0377-8401(02)00069-X

Maertens, L., Falcão-e-Cunha, L., \& Marounek, M. (2006). Feed additives to reduce the use of antibiotics. In L. Maertens \& P. Coudert (Eds.), Recent Advances in Rabbit Science (pp. 259-265). ILVO, Melle, Belgium.

McNitt, J. I., Dlukefahr, S., Cheeke, P. R., \& Patton, N. M. (2013). Rabbit production (9th ed.). CABI, UK. https://doi.org/10.1079/9781780640129.0000

Middleton, E., Kandaswami, C., \& Theoharides, T. C. (2000). The effects of plant flavonoids on mammalian cells: Implication for inflammation, heart disease and cancer. Pharmacol. Rev., 52(4), 673-682.

Morisse, J., Maurice, R., Boilletot, E., \& Cotte, J. (1993). Assessment of the activity of a fructo-oligosaccharide in different caecal parameters in rabbits experimentally infected with E. coli O103. Annual Zootecheical, 42, 81-87. https://doi.org/10.1051/animres:19930109

Mourão, J. L., Penheiro, V., Alves, A., Guedes, C. M., Pentol, L., Saavedra, M. J., ... Kocher, A. (2006). Effect of mannanoligo-Saccharides on the performance, intestinal morphology and cecal fermentation of fatting rabbits. Animal Feed Science and Technology, 126, 107-120. https://doi.org/10.1016/j.anifeedsci.2005. 06.009

Nakatain, N. (2003). Biologicacally functional constituents of spices and herbs. J. Jpn. Soc. Nutr. Food Sci., 56(6), 389-395. https://doi.org/10.4327/jsnfs.56.389

NRC (National Research Council). (1977). Nutrient Requirement of Rabbits. National Academy of Sciences (2nd ed.). National Research Council, Washington, DC., USA.

Oso, A., Richard, S., Vincent, J., Adeboye, F., OluwaseunSerah, I., Peter, D. B., \& Adesida, C. (2011). Effect of dietary inclusion of sorghum milling waste on growth response, nutrient utilization, gut characteristics and caecal microflora of weaner rcdabbits. Animal Science Journal, 82, 468-474. https://doi.org/10.1111/ j.1740-0929.2010.00862.x

Ouhayoun, J. (1998). Influence of the diet on rabbit meat quality. In C. de Blas \& J. Wiseman (Eds.), The Nutrition of the Rabbit (pp. 177-195). CAB Publishing, University Press, Cambridge.

Özkan, C., Kaya, A., \& Akgül, Y. (2012). Normal values of haematological and some biochemical parameters in serum and urine of New Zealand White rabbits. World Rabbit Sci., 20, 253-259. https://doi.org/10.4995/ wrs.2012.1229

Peeters, J. E., Maertens, L., \& Geeroms, R. (1992). Influence of galactooligosaccharides in zootechnical performance, cecal biochemistry and experimental colibacillosis $\mathrm{O} 103 / 8^{+}$in weanling rabbits. J. Appl. Rabbit Res., 15, 1129-1136.

Pelicano, E. R., Souza, P. A., Souza, H. B., Figueiredo, D. F., Boiago, M. M., Carvalho, S. R., \& Bordon, V. F. (2005). Intestinal mucosa development in broiler chickens fed natural growth promoters. Rev. Bras. Cienc. Avic., 4, 221-229. https://doi.org/10.1590/S1516-635X2005000400005 
Perez, J. M., Lebas, F., Gidenne, T., Maertens, L., Xiccato, G., Parigi-Bini, R., ... Bengala Freire, J. (1995). European reference method for in vivo determination of diet digestibility in rabbits. World Rabbit Sci., 3, 41-43. https://doi.org/10.4995/wrs.1995.239

Pinheiro, V., Alves, A., Mourão, J., Guedes, C., Pinto, L., Spring, P., \& Kocher, A. (2004). Effect of mannan oligosaccharides on the ileal morphometry and caecal fermentation of growing rabbits. Proceedings of the eighth World Rabbit Congress (pp. 936-941).

Rao, R. K., \& Samak, G. (2012). Role of glutamine in protection of intestinal epithelial tight junctions. J. of Epith. Biology and Pharmacology, 5(Suppl. 1-M7), 47-54.

Roberfroid, M. B. (2000). Prebiotics and Probiotics: Are they functional foods. Am. J. Clin. Nutr., 71, 1682-1687.

Robertson, J. (1988). Phytochemical characteristics of by-products of food and the digestion of starch and dietary fiber during gut transit. Proceedings of the $43^{\text {rd }}$ Nutrition Society (pp. 83-88). https://doi.org/ 10.1079/PNS19880024

Samanya, M., \& Yamauchi, K. E. (2002). Histological alterations of intestinal villi in chickens fed dried Bacillus subtilis var. natto. Comp. Bioch. and Physiol., Part A: Molecular \& Integrative Physiology, 133, 95-104. https://doi.org/10.1016/S1095-6433(02)00121-6

Sarhan, M. A. (2005). Utilization of agricultural and agro-industrial by-products of pea (PisiumSativum) in growing rabbit diets. Egypt. J. Rabbit Sci., 15(2), 157-172.

SAS Institute. (2004). SAS® User's Guide for personal computer. SAS Institute Inc., Cary, NC. USA.

Sawle, A., Higgins, M. K., Olivant, M. P., \& Higgins, J. A. (2002). A rapid single-step centrifugation method for determination of HDL, LDL, and VLDL cholesterol, and TG, and identification of predominant LDL subclass. J. Lipid Res., 43(2), 335-343.

Skřivanová, E., Hilary, J., Worgan, E., Eric, P., Milan, M., Jamie, C., \& Neil, M. (2010). Changes in the bacterial population of the caecum and stomach of the rabbit in response to addition of dietary caprylic Acid. Veterinary Microbiology, 144, 334-339. https://doi.org/10.1016/j.vetmic.2010.01.013

Tag El-Din, H. T., Abo-Egla, Al-Samra, H., Ismail, F. S. A., \& Samy, S. S. (2000). Utilization of sugar beet tops in feeding rabbits. Egypt. J. Rabbit Sci., 10(2), 223-238.

Taie, H. T., Abd El-Hady, Salwa, B., \& Abd El-Lateif, A. I. (1996). Utilization of sugar beet tops hay and silage in comparison to berseem in rabbits feeding. Egyptian J. Anim. Prod., 33, 443.

Trinder, P. (1969). Determination of glucose in blood using glucose oxidase with an alternative oxygen acceptor. Annals of Clinical Biochemistry, 6, 24-27. https://doi.org/10.1177/000456326900600108

Vernay, M., \& Marty, J. (1984). Absorption and metabolism of butyric acid in rabbit hind gut. Comp. Biochem. Physiol., 77, 89-96. https://doi.org/10.1016/0300-9629(84)90017-3

Wenk, C. (2003). Growth promoter alternatives after the ban on anti-biotics. Pig News and Information, 24(1), $11 \mathrm{~N}-16 \mathrm{~N}$.

Xia, M. S., Hu, C. H., \& Xu, Z. R. (2004). Effect of copper-bearing montmorillo-nite on growth performance, digestive enzyme activities, and intestinal microflora and morphology of male broiler. Poult. Sci., 83, 1868-1875. https://doi.org/10.1093/ps/83.11.1868

Xu, Z. R., Hu, C. H., \& Wang, M. Q. (2002). Effects of fructo-oligosaccharide on conversion of L-tryptophan to skatole and indole by mixed populations of pig fecal bacteria. J. Gen. Appl. Microbial., 48, 83-89. https://doi.org/10.2323/jgam.48.83

\section{Copyrights}

Copyright for this article is retained by the author(s), with first publication rights granted to the journal.

This is an open-access article distributed under the terms and conditions of the Creative Commons Attribution license (http://creativecommons.org/licenses/by/4.0/). 